Horáková, H.; Boscoboinik, A.; Smith, R. (eds.) (2018) Utopia and Neoliberalism: Ethnographies of Rural Spaces, Berlin: Lit-Verlag

\title{
Christian Ciordano
}

Emeritus Professor, University of Fribourg (Switzerland)

This volume is the result of a panel discussion at the $12^{\text {th }}$ conference of the Société Internationale d'Ethnologie et de Folklore, held in Zagreb in June 2015, whose theme was Utopias, Realities, Heritages: Ethnographies for the 21st Century. The panel addressed a central aspect of the theme selected by the conference organizers; that is the crucial dialectic and often conflicting relationship between utopian constructions of rural spaces that are often based on imaginary notions of rurality on the one hand, and neoliberal policies of a structural nature on the other.

In the opening and closing chapters, Hana Horakova and Andrea Boscoboinik discuss the volume's general theme and thus provide the theoretical framework that links the individual monographic articles and gives them a reciprocal coherence that is perhaps not immediately apparent given the books diverse fields and theoretical approaches.

In her very accurate, thorough and theoretically significant contribution, Hana Horáková points out how current rurality can no longer be analyzed via the classic dualism between rural and urban social worlds. In fact, the classic dichotomy between urbanity and rurality, so often employed in anthropology as well as in social sciences, yet already called into question in the 1970s by Oscar Lewis in the famous discussion with Robert Redfield, has become obsolete. As Horáková rightly highlights, the borders between rurality and urbanity have now become porous and thus invisible. The concept of rurality, therefore, can no longer be conceived in geographical terms, i.e. as an objective reality in contrast with urbanity. Accordingly, anthropologists ought to regard rurality as a social representation, i.e. as a reality resulting from the collective production of meaning in accordance with the interpretative approach. These days, rural areas are increasingly characterized by a spirit of urbanity spread by neo-rural social groups such as the new urban middle 
classes who move to the countryside either permanently or part-time. These classes are the major producers of utopian conceptions concerning neo-rurality, often in contrast with the representations and outlooks of the so-to-speak indigenous inhabitants, who instead perceive the arrival of these newcomers as a form of invasion. These situations clearly give rise to tensions, controversies and at times to actual conflicts between the various groups that make up this neo-rurality.

In her introduction, Hana Horáková also includes further theoretically significant details. For example, she highlights the current close relation between State, citizenship and market, which in the age of neoliberalism has distinctly shifted in favor of the market at the expense of the role of the State and especially of citizens. This substantial change may be regarded as the cause of ruralist nostalgia. On this point, I would add that the nostalgic shift referred to by Hana Horáková has also contributed to the current political success throughout Europe of populist, sovereigntist, secessionist and separatist parties, movements and governments.

In her afterword, Andrea Boscoboinik summarizes some of the themes dealt with by Hana Horáková in her introduction also through specific references to the volume's individual empirical chapters, thus based on in situ ethnographic researches. Especially worth mentioning is the authors emphasis on the close dialectic relation between utopia and dystopia. Andrea Boscoboinik underscores that utopian representations such as the present-day neo-rural ones are always linked to and built upon dystopian views of the reality in which the individual members of society live. Utopias are always built through dystopian representations; good and beautiful can always be defined in contrast with bad and ugly.

Between these two chapters with rather theoretical and thus methodologicalcharacteristics, the readerwillfind a series of ethnographic chapters based on long-term empirical fieldwork. Furthermore, all of the contributions analyze social realities in the Mediterranean and southeastern Europe (Catalonia, Sardinia, Romania, Macedonia and Croatia), except for two that are based on research conducted in the Swiss Alps (specifically the Canton of Vallais) and in China. 
This brief description already reveals a certain numerical and geographical imbalance between the various fields presented in this volume. Spain, specifically Catalonia, which is on the periphery of Spain in the Pyrenean mountain range, is the volume's pièce de résistance. Yet this apparent arbitrariness or randomness cannot be ascribed to either the two organizers or the participants as it is inherent to the type of international conference where the panel took place.

The first ethnographic chapter by Filippo Zerilli and Marco Pitzalis deals with pastoral Sardinia. The theme centers around the controversy between shepherds and animal husbandry experts. The shepherds seek to preserve their traditional animal welfare practices in opposition to procedures introduced by outside experts. However, there is no open conflict between shepherds and experts; rather, the former try to incorporate the neoliberal development strategies introduced by the latter in order to maintain, to some extent at least, their traditional-like rural utopia.

In the second chapter, Montserrat Soronellas-Masdeu and Gemma Casal-Fite analyze the practices of another rural utopia that aims to create methods that both differ from and resist the agricultural practices imposed by neoliberal policies. This rural utopia styles itself as agroecological and is particularly strong in the Catalan Pyrenees. Its aim is to challenge these external impositions by revitalizing the traditional role of farmers as producers of high-quality food. Ultimately, their efforts are focused on making clear the distinction between themselves and so-called organic agriculture, which still blindly adheres to neoliberal market rules. Furthermore, this distinction extends beyond the ambit of food production because the advocates of this agroecological utopia also deal with specific social issues.

The third chapter by Camila del Marmol also centers on a theme concerning Pyrenean Catalonia, namely capitalization processes in the rural world. For del Marmol, the crucial point is the meaning of the key term 'tradition'. In fact, discourses and therefore practices concerning the capitalization of tradition present a semantic contradiction because it imbues the concept with two different and contrasting meanings. Thus, 
from a neoliberal perspective, certain ways of capitalizing tradition are regarded as positive and should thus be promoted, whereas others are regarded as negative and should be stigmatized. In short, tradition and its capitalization are regarded as a plus if they are in line with neoliberal policies.

In the fourth chapter, Viviane Cretton cogently presents the rural ideal in Switzerland's Canton of Vallais and its pursuit by urbanites from all over Europe and the US. Economically well-off, these individuals emigrate at least temporarily to the canton's mountainous regions. Though in the past this rural mountain area has been represented as dreadful if not downright dangerous, it has now become an ideal location, that is, a form of utopia in many aspire to live. Viviane Cretton, however, expertly brings to the fore the power relations between center and periphery and between hegemonic and subaltern societies.

The fifth chapter by Yolanda Bodoque-Puerta again deals with Catalonia and analyzes the unusual and particularly interesting phenomenon of organized migration to rural areas by "caravans" chiefly consisting of foreign women from poorer societies seeking men willing to marry them and thus provide them with a more stable economic situation and higher social status. As the author convincingly shows, the potential husbands, most of whom are still primarily employed in agriculture, have little chance of marrying due to massive migration of local women to urban areas. As the author aptly highlights, these social practices are hardly consistent with utopian constructions of rurality.

The sixth chapter by Robin Smith centers on empirical research in a Croatian town that is nowadays located not far from the current Italian border but which up to the end of World War II lay within the Italian state. The author's argument is based on the concept of solastalgia, i.e. a specific form of nostalgia caused by the loss of one's rural landscape and thus one's own environment. As may well be imagined, this nostalgic perspective looks first and foremost back to the days of the former Yugoslavia. 
In the seventh chapter, Karolina Bielenin-Lenczowska reconstructs the current situation in a marginal and peripheral area of present-day Macedonia eighty years after research conducted by Jozef Obrebski, a pupil of Bronislaw Malinowski. The author points out the differences between the various representations of rurality amongst the different groups, these being permanent residents, newcomers and those who left their place of origin. The resulting picture is rather varied and is dominated by a nostalgic vision of a peaceful rural past on the one hand, and a conservative and somewhat wistful recollection of life in the former Yugoslavia.

In the eighth chapter, Vintila Mihailescu and Virginia Dumineca deal with many of the themes tackled in the previous contributions. Thus, the two authors show that in peripheral Romania, the members of an agropastoral society continue to practice their traditional activities whilst at the same time having to comply with new EU norms. In order to survive, these agro-pastoral societies have had to open up their farms and homes to urban tourists in nostalgic pursuit of a more or less fictional rurality.

The ninth and last chapter by Eveline Bingaman represents an important counterpoint to the other contributions because the author presents her ethnographic research carried out in highly socially and culturally complex areas of the People's Republic of China. The author focuses on the complicated and often tense relations between the local rural population and tourists from the wealthier regions of eastern China. The article, therefore, centers on the analysis of two opposite conceptions of rurality, i.e. that of the Han majority and that of the members of a rather marginal and marginalized ethnic minority. Despite the significant geographical relocation, the article does not stand out in the book's overall structure because its theme is linked to that of other contributions (such as those by Viviane Cretton and Karolina BieleninLenczowska).

In conclusion, I would like to stress that this is a very stimulating book both in terms of theoretical reflection and ethnographic richness. Despite the different fields and theoretical affiliations, the book has a clear leitmotiv characterized by the relations between rurality/urbanity 
and between utopia/dystopia. That said, the theme of neoliberal policies, whilst certainly topical, is in my view dealt with conventionally and not thoroughly enough as a secondary issue.

A final criticism is that the volume revolves around an excessive presentism. Aside from some brief references in Hana Horakova's introduction, historical references are rather wanting. In fact, the phenomena and processes presented and, rightly or not, ascribed to the neoliberal shift are but a minute variation on a topos that I would venture to define as age-old; that is, the close relation between rurality and utopia/ dystopia. Without going into historical-philosophical details, ever since Greco-Roman pastoral poetry these utopias/dystopias have been a literary constant and, in some instances, have actually been practiced in real life. In the world of literature we have Walden; or, Life in the Woods by Henry David Thoreau and James Joyce's avowed anti-urbanity with his famous correlation between civilization and syphilization. Likewise, for real-life examples, I need only reference the attempt of a small group of Swiss anarchists to create an egalitarian rural community in Paraguay, which paradoxically was located near the one created by Dr. Bernhard Förster and his wife Alexandra Nietzsche (sister of the philosopher Friedrich Nietzsche) who, instead, had set out to create an agricultural community of pure Aryan Germans. Both of these ideologically opposed attempts failed miserably. We should also recall the intended rural utopia of the Jonestown community that turned into a totalitarian dystopia and ended in tragic collective suicide in 1978.

Returning to more recent phenomena regarding attempts to escape civilization, we ought to mention the book Versuche der Ziviliastion zu entkommen by Ina-Maria Greverus and Erika Haindl published in 1983. In the late 1970s - early 1980s, the two German anthropologists, drawing from the philosopher Ernst Bloch, highlighted the close connection between utopia and rurality in late modernity. Their reflections on the apparent need for utopias, especially rural and ecological ones, were based on empirical data gathered from communities then known as alternative and which had retreated to rural locations to escape urban civilization. However, unsurprisingly the book makes no mention of 
neoliberal policies given that at the time these were in their infancy nowhere near as well entrenched as they are today.

I therefore believe that Utopia and Neoliberalism: Ethnographies of Rural Spaces would have been even more consistent if the authors had referred to Das Prinzip Hoffnung, the outstanding and encyclopedic book by Ernst Bloch (published between 1954 and 1959 in the GDR) that is cited to a limited extent by Hana Horáková in her excellent introduction. 